\title{
New Insecticidal Antibiotics, Hydroxyfungerins A and B, Produced by Metarhizium sp. FKI-1079
}

\author{
Ryuji Uchida, Rie Imasato, Yuichi Yamaguchi, Rokuro Masuma, Kazuro Shiomi, \\ Hiroshi Tomoda, Satoshi Ōmura
}

Received: September 26, 2005 / Accepted: December 5, 2005

(C) Japan Antibiotics Research Association

\begin{abstract}
New insecticidal antibiotics designated hydroxyfungerins $\mathrm{A}$ and $\mathrm{B}$ were isolated from the culture broth of a fungal strain Metarhizium sp. FKI-1079 together with a known compound, fungerin. The structures of hydroxyfungerins $\mathrm{A}$ and $\mathrm{B}$ were elucidated by spectroscopic studies including various NMR experiments. Hydroxyfungerins $\mathrm{A}$ and $\mathrm{B}$ showed growth inhibitory activity against brine shrimps, Artemia salina.
\end{abstract}

Keywords fungerin, insecticidal, brine shrimp, fungi, Metarhizium sp.

\section{Introduction}

Our research group has focused on discovery of biological active compounds from microbial metabolites [1 8]. In the course of our screening program for insecticidal antibiotics, we found that a fungal strain FKI-1079, which was isolated from soil collected at Yakushima, Kagoshima Prefecture, Japan, produced two new insecticidal antibiotics, named hydroxyfungerins A (2) and B (3), along with the known compound, fungerin (1) [9] (Fig. 1). The strain was identified as Metarhizium sp. from morphogical characteristics. Compounds $\mathbf{2}$ and $\mathbf{3}$ were structurally related to $\mathbf{1}$, previously reported antifungal antibiotic active against Penicillium chrysogenum, Colletorichum langenarium, Altenaria mali and Pyricularia oryzae [9]. In this paper, the taxonomy of the producing fungus and the fermentation, isolation, structure elucidation and biological properties of hydroxyfungerins are described. Furthermore, biological activities of $\mathbf{1}$ previously reported to have antifungal activity are also described.<smiles>COC(=O)/C=C/c1ncn(C)c1CC=C(C)C</smiles>

1<smiles>COC(=O)/C=C/c1ncn(C)c1C/C=C(\C)CO</smiles>

2<smiles>COC(=O)/C=C/c1c(C/C=C(\C)CO)ncn1C</smiles>

3

Fig. 1 Structures of fungerin (1) and hydroxyfungerin A (2) and B (3).

H. Tomoda (Corresponding author), R. Uchida: School of Pharmaceutical Sciences, Kitasato University, 5-9-1 Shirokane, Minato-ku, Tokyo 108-8641, Japan,

E-mail:tomoda@lisci.kitasato-u.ac.jp
R. Imasato, Y. Yamaguchi, R. Masuma, K. Shiomi, S. Ōmura: Kitasato Institute for Life Sciences, \& Graduate School of Infection Control Sciences, Kitasato University and The Kitasato Institute, 5-9-1 Shirokane, Minato-ku, Tokyo 108-8641, Japan 


\section{Materials and Methods}

\section{General}

NMR spectra were recorded on a Varian Inova 600 spectrometer $\left({ }^{2-3} J_{\mathrm{CH}}=8 \mathrm{~Hz}\right.$ in $\left.\mathrm{HMBC}\right)$. Chemical shifts are shown in $\delta$ values (ppm) relative to chloroform- $d_{1}$ at $7.26 \mathrm{ppm}$ for ${ }^{1} \mathrm{H}$ NMR and at $77.0 \mathrm{ppm}$ for ${ }^{13} \mathrm{C}$ NMR. FAB mass spectrometry was conducted on a JEOL JMSAX505H spectrometer. UV and IR spectra were measured with a Beckman DU640 spectrophotometer and a Horiba FT-210 Fourier transform infrared spectrometer, respectively.

\section{Taxonomic Studies of the Producing Organism}

Strain FKI-1079 was isolated from a soil sample collected at Yakushima Island, Kagoshima Prefecture, Japan. For the taxonomic studies of the fungus, potato dextrose agar (PDA, Difco), malt extract agar (MEA), cornmeal agar (CMA, Difco) and Miura's medium (LcA) were used. Morphological observations were made under a light microscope (Olympus Vanox-S AH-2) and a scanning electron microscope (JEOL JSM-5600). Color names and hue numbers were determined according to the Color Harmony Manual, 4th Ed [10].

\section{Fermentation}

A stock culture of strain FKI-1079 was inoculated into a 500-ml Erlenmeyer flask containing $100 \mathrm{ml}$ of the seed medium (glucose $2.0 \%$, yeast extract (Oriental Yeast Co.) $0.2 \%, \mathrm{MgSO}_{4} \cdot 7 \mathrm{H}_{2} \mathrm{O} 0.05 \%$, Polypepton (Daigo Nutritive Chemicals) $0.5 \%, \mathrm{KH}_{2} \mathrm{PO}_{4} 0.1 \%$ and agar $0.1 \%, \mathrm{pH} 6.0$ ) and incubated on a rotary shaker at $27^{\circ} \mathrm{C}$ for 4 days. The main culture was initiated by transferring $2 \mathrm{ml}$ of the seed culture into each of thirty 1-liter Roux flask containing $200 \mathrm{ml}$ of production medium (rice (Nichiou syouji Co.) $150 \mathrm{~g}, \quad \mathrm{FeSO}_{4} \cdot 7 \mathrm{H}_{2} \mathrm{O} 90 \mathrm{mg}, \mathrm{MnCl}_{2} \cdot 4 \mathrm{H}_{2} \mathrm{O} 90 \mathrm{mg}$, $\mathrm{ZnSO}_{4} \cdot 7 \mathrm{H}_{2} \mathrm{O} 90 \mathrm{mg}, \mathrm{CuSO}_{4} \cdot 7 \mathrm{H}_{2} \mathrm{O} 90 \mathrm{mg}, \mathrm{CoCl}_{2} \cdot 6 \mathrm{H}_{2} \mathrm{O}$ $90 \mathrm{mg}$ and tap water $90 \mathrm{ml}$ ) and the fermentation was carried out at $27^{\circ} \mathrm{C}$ for 15 days on stationary culture.

\section{Insecticidal Activity}

Insecticidal activity was assayed by a microtiter-plate assay using brine shrimps, A. salina (Pfizer Consumer Inc) as reported previously [11]. Briefly, about 10 nauplii larvae hatched from eggs of brine shrimps were incubated with a test sample in a well of 96-well microplates at room temperature. After 48 hours, the motility of brine shrimps was assessed visually in comparison with controls (no samples).

\section{Nematocidal Activity}

Nematocidal activity was assayed by a microtiter-plate assay using the free-living nematode, Caenorhabditis elegans, as reported previously [11]. Briefly, C. elegans was cultivated on an agar plate covered with Escherichia coli for 4 days at $20^{\circ} \mathrm{C}$ and the grown nematodes were used for assay. These organisms were incubated with a sample in a well of a 96 -well micoroplate at $20^{\circ} \mathrm{C}$. After 48 hours, the motility of the nematoda was assessed visually under a microscope $(\times 40$, Olympus CK2) in comparison with controls (no samples).

\section{Antimicrobial Activity}

Antimicrobial activity against 14 species of microorganisms was measured by a paper disk method. The media for microorganisms are as follows: GAM agar (Nissui Seiyaku Co.) for Bacteroides fragilis; Waksman agar for Mycobacterium smegmatis; Bacto PPLO agar (Difco) supplemented with $15 \%$ horse serum, glucose $0.1 \%$, phenol red $(5 \mathrm{mg} / \mathrm{ml}) \quad 0.2 \%$ and agar $1.5 \%$ for Acholeplasma laidlawii; nutrient agar for Bacillus subtilis, Staphylococcus aureus, Micrococcus luteus, Escherichia coli, Pseudomonas areginosa and Xanthomonas oryzae; a medium composed of glucose $1.0 \%$, yeast extract $0.5 \%$, and agar $0.8 \%$ for Pyricularia oryzae, Aspergillus niger, Mucor racemosus, Candida albicans and Saccharomyces cerevisiae. A paper disk (i.d. $6 \mathrm{~mm}$, Advantec) containing $10 \mu \mathrm{g}$ of a sample was placed on the agar plate. Bacteria, except $X$. oryzae, were incubated at $37^{\circ} \mathrm{C}$ for 24 hours. Yeasts and $X$. oryzae were incubated at $27^{\circ} \mathrm{C}$ for 24 hours. Fungi were incubated at $27^{\circ} \mathrm{C}$ for 48 hours. Antimicrobial activity was expressed as the diameter $(\mathrm{mm})$ of the inhibitory zone.

\section{Results}

\section{Taxonomy of the Producing Organism}

Colonies of strain FKI-1079 on the media were $20 \sim 30 \mathrm{~mm}$ in diameter after 7 days at $25^{\circ} \mathrm{C}$, floccose to velutinous, white (a) or olive (1 pl) to dark olive (1 pn) in color. The reverse side was white (a) to light ivory $(2 \mathrm{ca})$. On each medium, the conidiostroma, consisting of sporodochial conidiophores and conidia, were abundantly formed (Fig. 2 ). The conidiophores were composed of $3 \sim 4$ branches of $40 \sim 50 \mathrm{~mm}$ in length. The cylindrical phialides were formed at the tip of branches and $10 \sim 15 \times 2.0 \sim 2.5 \mu \mathrm{m}$ in size. The phialospores were unicellular, cylindrical, pale green, produced in chains, adhering in tall, columnar aggregates and $6 \sim 7.5 \times 2 \sim 3.0 \mu \mathrm{m}$ in size. From the above characteristics, strain FKI-1079 was considered to belong 
to the genus Metarhizium $[12,13]$ and named Metarhizium sp. FKI-1079.

\section{Isolation}

The isolation procedure for the hydroxyfungerins is summarized in Fig. 3. The cultured broth (6 liters) was treated with EtOH (6 liters) for 1 hour. Then, the extracts were concentrated under reduced pressure to remove EtOH and extracted with EtOAc. After drying over $\mathrm{Na}_{2} \mathrm{SO}_{4}$, the organic layer was concentrated under reduced pressure to give a brown paste $(3.9 \mathrm{~g})$. This was applied to a silica gel column (120 g, Silica gel 60, 63 200 $\mu \mathrm{m}$, Merck) prepared with $\mathrm{CHCl}_{3}$, and eluted with $\mathrm{CHCl}_{3}$ and $\mathrm{CHCl}_{3}-\mathrm{MeOH}$. The fractions eluted with $\mathrm{CHCl}_{3}-\mathrm{MeOH}(50: 1)$ were collected and concentrated under reduced pressure to give a yellow powder containing 1 . This powder $(361 \mathrm{mg})$ was washed with hexane and treated with $\mathrm{MeOH}$, and the $\mathrm{MeOH}$ soluble fraction was concentrated under reduced

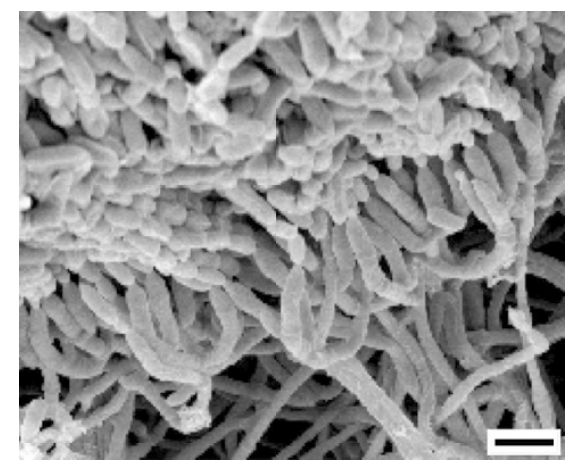

Fig. 2 SEM photomicrograph of sympodially produced conicedia of FKI-1079.

Bar represents $20 \mu \mathrm{m}$. pressure to give a pale yellow powder. It was further purified by preparative HPLC (mobile phase: $40 \% \mathrm{CH}_{3} \mathrm{CN}$; flow rate, $8 \mathrm{ml} /$ minute; detection, UV $300 \mathrm{~nm}$ ) using an ODS column under the following conditions: column (CAPCEL PAK C18 UG120: 20 i.d. $\times 250 \mathrm{~mm}$, SISEIDO Co., Ltd.; temperature, $40^{\circ} \mathrm{C}$ ). The active fraction eluted at 20 minutes was concentrated to dryness to give a white powder of pure $1(25.5 \mathrm{mg})$. On the other hand, the fractions eluted with $\mathrm{CHCl}_{3}-\mathrm{MeOH}(20: 1)$ were collected and concentrated under reduced pressure to give a yellow powder containing 2 and $\mathbf{3}(160 \mathrm{mg})$. This was applied to an ODS column (10 g, PEGASIL PREP ODS-7515-12-A, Senshu Co., Ltd) prepared with water, and eluted with $\mathrm{CH}_{3} \mathrm{CN}-\mathrm{H}_{2} \mathrm{O}$ solvents. The fractions eluted with $\mathrm{CH}_{3} \mathrm{CN}-$ $\mathrm{H}_{2} \mathrm{O}(2: 3)$ were collected and concentrated under reduced pressure to give a yellow powder containing $\mathbf{2}$ and $\mathbf{3}$ $(18.3 \mathrm{mg})$. These compounds were finally separated and purified by preparative HPLC (mobile phase: $13 \% \mathrm{CH}_{3} \mathrm{CN}$; flow rate, $8 \mathrm{ml} /$ minute; detection, UV $300 \mathrm{~nm}$ ) using an ODS column under the following conditions: column (CAPCEL PAK C18 UG120: 20 i.d. $\times 250 \mathrm{~mm}$, SISEIDO Co., Ltd.; temperature, $40^{\circ} \mathrm{C}$ ). The active fractions eluted at 47 and 49 minutes were concentrated to dryness to give white powders of pure $\mathbf{2}(1.2 \mathrm{mg})$ and $\mathbf{3}(0.8 \mathrm{mg})$, respectively.

\section{Physico-chemical Properties}

The physico-chemical properties of $\mathbf{1} \sim \mathbf{3}$ are summarized in Table 1. They are soluble in methanol, acetone, chloroform and DMSO. The molecular formulae of $\mathbf{1} \sim \mathbf{3}$ were revealed to be $\mathrm{C}_{13} \mathrm{H}_{18} \mathrm{~N}_{2} \mathrm{O}_{2}, \mathrm{C}_{13} \mathrm{H}_{18} \mathrm{~N}_{2} \mathrm{O}_{3}$ and $\mathrm{C}_{13} \mathrm{H}_{18} \mathrm{~N}_{2} \mathrm{O}_{3}$ by HRFAB-MS, respectively. The UV spectra of $\mathbf{1} \sim \mathbf{3}$ exhibited a characteristic absorption maximum at $305 \mathrm{~nm}$ in methanol. The IR spectra were also similar. These data indicated that

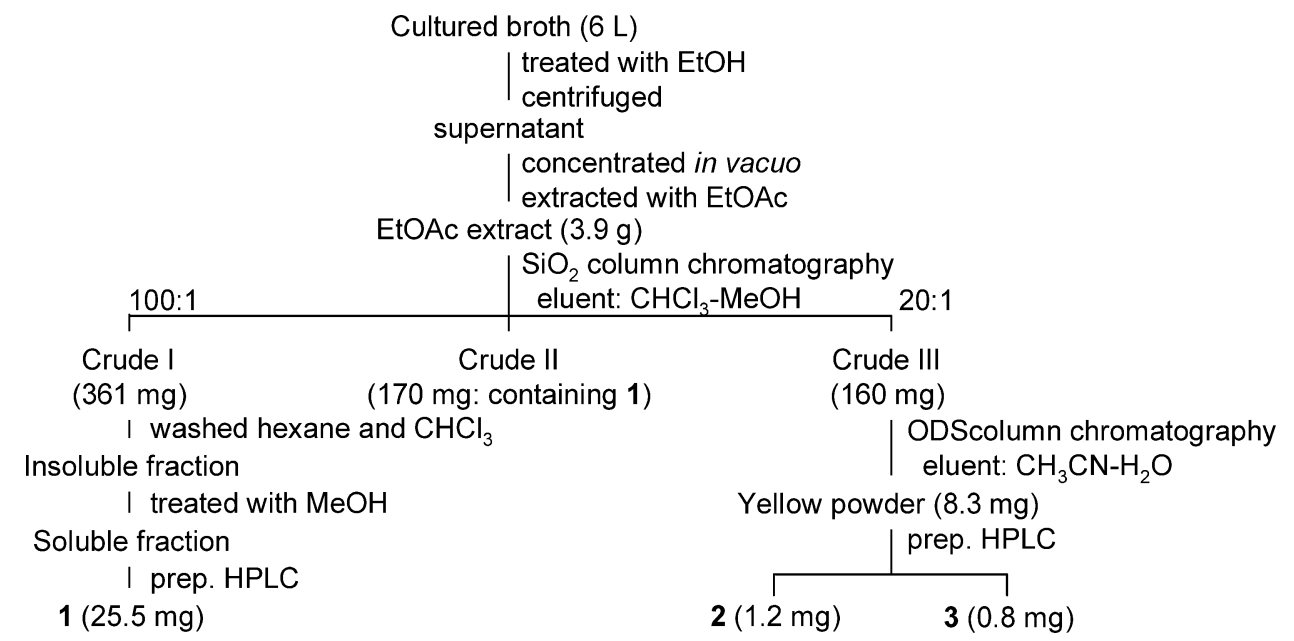

Fig. 3 Purification procedures of fungerin and hydroxyfungerins from the culture broth of Metarhizium sp. FKI-1079. 
Table 1 Physico-chemical properties of $\mathbf{1}$ to $\mathbf{3}$

\begin{tabular}{|c|c|c|c|}
\hline & 1 & 2 & 3 \\
\hline Appearance & Pale yellow powder & Pale yellow powder & Pale yellow powder \\
\hline Molecular weight & 234 & 250 & 250 \\
\hline Molecular formula & $\mathrm{C}_{13} \mathrm{H}_{18} \mathrm{~N}_{2} \mathrm{O}_{2}$ & $\mathrm{C}_{13} \mathrm{H}_{18} \mathrm{~N}_{2} \mathrm{O}_{3}$ & $\mathrm{C}_{13} \mathrm{H}_{18} \mathrm{~N}_{2} \mathrm{O}_{3}$ \\
\hline \multicolumn{4}{|l|}{ HRFAB-MS } \\
\hline Calcd & $234.1368(\mathrm{M})^{+}$ & $250.1317(\mathrm{M})^{+}$ & $250.1317(\mathrm{M})^{+}$ \\
\hline Found & $234.1360(\mathrm{M})^{+}$ & $250.1325(\mathrm{M})^{+}$ & $250.1317(\mathrm{M})^{+}$ \\
\hline UV $\lambda_{\max } \mathrm{nm}(\varepsilon)$ in $\mathrm{MeOH}$ & $300(28,000)$ & $305(27,000)$ & $305(27,200)$ \\
\hline $\mathrm{IR} v_{\max } \mathrm{cm}^{-1}(\mathrm{KBr})$ & $\begin{array}{c}2775,1866,1704 \\
1630,1432,1384 \\
1303\end{array}$ & $\begin{array}{c}3430,2766,1702 \\
1689,1433,1303\end{array}$ & $\begin{array}{c}3421,2782,1700 \\
1674,1435,1323\end{array}$ \\
\hline \multicolumn{4}{|l|}{ Solubility } \\
\hline Soluble & $\begin{array}{c}\mathrm{CHCl}_{3}, \mathrm{MeOH}, \\
\text { acetone, EtOAc, } \\
\text { DMSO }\end{array}$ & $\begin{array}{c}\mathrm{CHCl}_{3}, \mathrm{MeOH}, \\
\text { acetone, EtOAc, } \\
\text { DMSO }\end{array}$ & $\begin{array}{c}\mathrm{CHCl}_{3}, \mathrm{MeOH}, \\
\text { acetone, EtOAc, } \\
\text { DMSO }\end{array}$ \\
\hline Insoluble & Hexane, $\mathrm{H}_{2} \mathrm{O}$ & Hexane, $\mathrm{H}_{2} \mathrm{O}$ & Hexane, $\mathrm{H}_{2} \mathrm{O}$ \\
\hline
\end{tabular}

Table $2{ }^{1} \mathrm{H}$ and ${ }^{13} \mathrm{C}$ NMR chemical shifts of $\mathbf{1}$ to $\mathbf{3}$

\begin{tabular}{|c|c|c|c|c|c|c|}
\hline \multirow{2}{*}{ Position } & \multicolumn{2}{|r|}{1} & \multicolumn{2}{|r|}{2} & \multicolumn{2}{|r|}{3} \\
\hline & $\begin{array}{l}{ }^{13} \mathrm{C} \text { chemical } \\
\text { shifts }(\mathrm{ppm})^{\mathrm{a})}\end{array}$ & $\begin{array}{l}{ }^{1} \mathrm{H} \text { chemical shifts } \\
(\mathrm{ppm})^{\mathrm{b})}\end{array}$ & $\begin{array}{l}{ }^{13} \mathrm{C} \text { chemical } \\
\text { shifts }(\mathrm{ppm})^{\mathrm{a}, \mathrm{c})}\end{array}$ & $\begin{array}{c}{ }^{1} \mathrm{H} \text { chemical shifts } \\
(\mathrm{ppm})^{\mathrm{b})}\end{array}$ & $\begin{array}{l}{ }^{13} \mathrm{C} \text { chemical } \\
\left.\text { shifts (ppm) }{ }^{\mathrm{a}, \mathrm{c}}\right)\end{array}$ & $\begin{array}{l}{ }^{1} \mathrm{H} \text { chemical shifts } \\
(\mathrm{ppm})^{\mathrm{b})}\end{array}$ \\
\hline 1 & 168.5 & $s-$ & 168.4 & $s-$ & 168.0 & $s-$ \\
\hline 2 & 114.2 & $\mathrm{~d} 6.65 \mathrm{~d}(J=15.4 \mathrm{~Hz})$ & 116.4 & $\mathrm{~d} 6.67 \mathrm{~d}(J=15.6 \mathrm{~Hz})$ & 115.0 & d $6.79 \mathrm{~d}(J=15.6 \mathrm{~Hz})$ \\
\hline 3 & 135.2 & d $7.72 \mathrm{~d}(J=15.4 \mathrm{~Hz})$ & 133.4 & $d 7.57 \mathrm{~d}(J=15.6 \mathrm{~Hz})$ & 132.0 & d $7.55 \mathrm{~d}(J=15.6 \mathrm{~Hz})$ \\
\hline 4 & 134.0 & $s-$ & 133.0 & $s-$ & 133.5 & $s-$ \\
\hline 5 & - & - & - & - & - & - \\
\hline 6 & 138.0 & d $7.5 \mathrm{~s}$ & 138.2 & d 7.78 br.s & 137.8 & d 8.17 brs \\
\hline 7 & - & - & - & - & - & - \\
\hline 8 & 134.2 & $s-$ & 133.7 & $s-$ & 133.4 & $s-$ \\
\hline 9 & 22.4 & t $3.51 \mathrm{~d}(\mathrm{~J}=7.0 \mathrm{~Hz})$ & 22.6 & t $3.55 \mathrm{~d}(\mathrm{~J}=6.6 \mathrm{~Hz})$ & 22.5 & t $3.47 \mathrm{~d}(J=6.6 \mathrm{~Hz})$ \\
\hline 10 & 119.3 & d $5.13 \mathrm{t}(\mathrm{J}=7.0 \mathrm{~Hz})$ & 122.0 & d 5.19 t $(J=6.6 \mathrm{~Hz})$ & 118.6 & d $5.36 \mathrm{t}(\mathrm{J}=6.6 \mathrm{~Hz})$ \\
\hline 11 & 134.3 & $s-$ & 137.6 & $s-$ & 138.9 & $s-$ \\
\hline 12 & 25.5 & $\mathrm{q} 1.87 \mathrm{~s}$ & 61.6 & $\mathrm{t} 4.29 \mathrm{~s}$ & 67.8 & $\mathrm{t} 4.00 \mathrm{~s}$ \\
\hline 13 & 18.0 & $\mathrm{q} 1.83 \mathrm{~s}$ & 21.6 & $\mathrm{q} 1.82 \mathrm{~s}$ & 14.0 & $\mathrm{q} 1.78 \mathrm{~s}$ \\
\hline $\mathrm{OCH}_{3}$ & 51.4 & q $3.87 \mathrm{~s}$ & 51.5 & q $3.77 \mathrm{~s}$ & 51.8 & q $3.75 \mathrm{~s}$ \\
\hline $\mathrm{NCH}_{3}$ & 31.6 & $\mathrm{q} 3.66 \mathrm{~s}$ & 32.3 & q $3.64 \mathrm{~s}$ & 32.8 & q $3.67 \mathrm{~s}$ \\
\hline
\end{tabular}

a) Chemical shifts are shown with reference to $\mathrm{CDCl}_{3}$ as $77.0 \mathrm{ppm}$. ${ }^{\text {b) }}$ Chemical shifts are shown with reference to $\mathrm{CDCl}_{3}$ as $7.26 \mathrm{ppm}$. ${ }^{\text {c) }}{ }^{13} \mathrm{C}$ chemical shifts and the multiplicit of the ${ }^{13} \mathrm{C}$ NMR signals were determined from HMOC and HMBC data.

these compounds are structurally related. Compound $\mathbf{1}$ was identified as the known compound fungerin previously reported as an antifungal antibiotic [9].

\section{Structure Elucidation}

The structures of $\mathbf{2}$ and $\mathbf{3}$ were elucidated by extensive
NMR experiments in $\mathrm{CDCl}_{3}$. The assignment of the ${ }^{1} \mathrm{H}$ and ${ }^{13} \mathrm{C}$ NMR signals was facilitated by ${ }^{1} \mathrm{H}-{ }^{1} \mathrm{H}$ COSY and ${ }^{13} \mathrm{C}-$ ${ }^{1} \mathrm{H}$ HMQC experiments (Table 2). The data for $\mathbf{1}$ are also shown in Table 2 for comparative purposes.

Structure of 2: The ${ }^{1} \mathrm{H}$ and ${ }^{13} \mathrm{C}$ NMR spectra (Table 2) resembled those of $\mathbf{1}$ except for the proton and carbon 


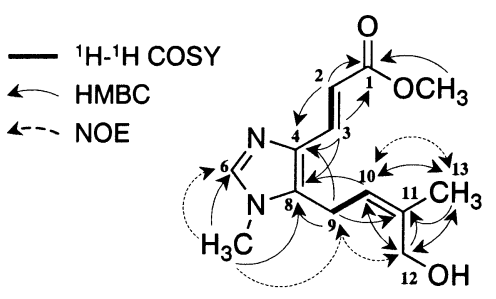

2

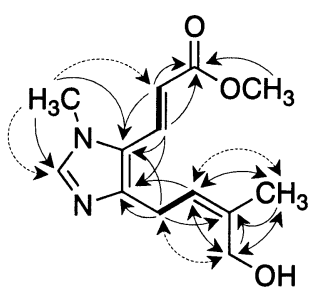

3
Fig. $4{ }^{1} \mathrm{H}-{ }^{1} \mathrm{H}$ COSY, HMBC and NOE experiments for 2 and 3.

signals of $\mathrm{C}-12$. The ${ }^{13} \mathrm{C}-{ }^{1} \mathrm{H}$ long-range couplings of ${ }^{2} J$ and ${ }^{3} J$ in the HMBC experiments are shown in Fig. 4, giving the following results. The cross peaks from $12-\mathrm{H}_{2}(\delta 4.29)$ to the $s p^{2}$ methine carbon $\mathrm{C}-10\left(\begin{array}{l}\delta \\ 122.0)\end{array}\right)$, the $s p^{2}$ quaternary carbon $\mathrm{C}-11(\delta$ 137.6) and the methyl carbon $\mathrm{C}$ $13\left(\delta\right.$ 21.6), from $10-\mathrm{H}(\delta 5.19)$ and $13-\mathrm{H}_{3}(\delta 1.82)$ to oxymethylene carbon $\mathrm{C}-12,(\delta 61.6)$ indicated that 2 has a hydroxymethyl residue at $\mathrm{C}-12$ instead of the methyl group of 1. From NOE experiments as shown in Fig. 4, NOEs were observed between $9-\mathrm{H}_{2}$ and $12-\mathrm{H}_{3}$ and $10-\mathrm{H}$ and $13-$ $\mathrm{H}_{3}$, indicating that the double bond between C-10 and C-11 has the $Z$-isomer. Furthermore, an NOE was observed between the $\mathrm{N}$-methyl proton and $9-\mathrm{H}$, consistent with attachment of the $N$-methyl group at position 7 of the imidazole ring. Taking these data together, the structure of 2 was elucidated as shown in Fig. 4.

Structure of 3: The ${ }^{1} \mathrm{H}$ and ${ }^{13} \mathrm{C}$ NMR spectra (Table 2) resembled those of 2 except for the proton signal of $6-\mathrm{H}$ ( $\delta$ 8.17). The analysis of HMBC experiments revealed the structure of 3 as shown in Fig. 4 . The ${ }^{13} \mathrm{C}-{ }^{1} \mathrm{H}$ long-range couplings were observed from the $N$-methyl proton $(\delta 3.67)$ to the $s p^{2}$ methine carbon C-6 $\left(\delta\right.$ 137.8) and the $s p^{2}$ quaternary carbon C-8 $(\delta$ 133.4), indicating that the $N$ methyl group of $\mathbf{3}$ is attached at position 5 of the imidazole ring. Furthermore, an NOE was observed between $N$ methyl proton and $2-\mathrm{H}_{2}$, supporting the proposed structure.

\section{Biological Activitiess}

Insecticidal activity

The insecticidal activities of $\mathbf{1} \sim \mathbf{3}$ were studied in a microplate assay using the brine shrimp Altemia salina. Minimum growth inhibitory concentrations (MIC) were summarized in Table 3. Compound $\mathbf{1}$ was the most potent with a MIC value of $0.39 \mu \mathrm{g} / \mathrm{ml}(1.7 \mu \mathrm{M})$. Compounds 2 and 3 exhibited moderate inhibition with MICs of $6.25 \mu \mathrm{g} / \mathrm{ml}(25 \mu \mathrm{M})$.
Table $\mathbf{3}$ Incecticidal and nenatocidal activities of $\mathbf{1}$ to $\mathbf{3}$

\begin{tabular}{ccc}
\hline & \multicolumn{2}{c}{$\operatorname{MIC}(\mu \mathrm{g} / \mathrm{ml})$} \\
\cline { 2 - 3 } Compound & A. salina & C. elegans \\
\hline $\mathbf{1}$ & 0.39 & 6.25 \\
$\mathbf{2}$ & 6.25 & $>50$ \\
$\mathbf{3}$ & 6.25 & $>50$ \\
\hline
\end{tabular}

Nematocidal Activity

The nematocidal activities of $\mathbf{1} \sim \mathbf{3}$ were studied in a microplate assay using the free-living nematode, Caenorhabditis elegans. The MICs are summarized in Table 3. Compound 1 was the most potent with a MIC value of $6.25 \mu \mathrm{g} / \mathrm{ml}(27 \mu \mathrm{M})$, while 2 and $\mathbf{3}$ showed almost no activity at $50 \mu \mathrm{g} / \mathrm{ml}$.

Antimicrobial Activity

Compounds 1 3 showed no antimicrobial activity against 14 microorganisms as described at $10 \mu \mathrm{g} / 6 \mathrm{~mm}$ disk.

\section{Discussion}

Fungerin (1) was originally isolated as an antifungal antibiotic from a Fusarium sp., and subsequently reported [9]. As shown in this paper, 1 was also produced by a different fungus a Metarhisium sp. FKI-1079. Visoltricin, a positional isomer at the $N$-methyl position of $\mathbf{1}$, was reported to show anti- $A$. salina activity and cholinesterase inhibitory activities $[14,15]$. However, a recent synthetic study resulted in a revised structure identical to 1 [16]. In this sense, we only confirmed the anti- $A$. salina activity of 1 as described above, and the potency (MIC $1.3 \mu \mathrm{M}$ ) seemed almost the same as that $(0.85 \mu \mathrm{M})$ reported [15]. Interestingly, the $\mathrm{N}$-methyl position of the imidazole ring in hyroxyfungerin $B$ is the same as that of original visoltricin. Therefore, it may be plausible that visoltricin is produced by this fungus, although it was not isolated from the culture broth.

Regarding the biological activities of fungerins, a similar order of potency was observed in insecticidal and nematocidal activities (Table 3); $\mathbf{1}$ is the most potent, followed by $\mathbf{2}$ and $\mathbf{3}$. These results suggested that the hydroxy residues in the terminal isoprene moiety is detrimental to these biological activities. As reported previously, $\mathbf{1}$ causes M phase arrest in Jurkat cells (a cell line from human $\mathrm{T}$ cell leukemia) by inhibiting microtubule polymerization [17]. Therefore, these anti- $A$. salina and 
anti-C. elegans activities might be caused by the microtubule action by $\mathbf{1}$.

Acknowledgements We are grateful to Mrs. Akiko Nakagawa, Mrs. Chikako Sakabe and Noriko Sato, School of Pharmaceutical Sciences, Kitasato University for measurements of mass and NMR spectra. This work was supported in part by Grand-in-Aid for the 21st Century COE Program "Discovery of anti-infectionus drugs from natural resources and its basic studies" and for Scientific Research on Priority Areas 16073215 from the Ministry of Education, Culture, Sports, Science and Technology, Japan.

\section{References}

1. Fukuda T, Arai M, Tomoda H, Ōmura S. New beauvericins, potentiators of antifungal miconazole activity, Produced by Beauveria sp. FKI-1366. II. Structure elucidation. J Antibiot 57: 117-124 (2004)

2. Fukuda T, Arai M, Yamaguchi Y, Masuma R, Tomoda H, Ōmura S. New beauvericins, potentiators of antifungal miconazole activity, Produced by Beauveria sp. FKI-1366. I. Taxonomy, fermentation, isolation and biological properties J Antibiot 57: 110-116 (2004)

3. Matsuda D, Namatame I, Tomoda H, Kobayashi S, Zocher R, Kleinkauf H, Ōmura S. New beauveriolides produced by amino acid-supplemented fermentation of Beauveria sp. FO-6979. J Antibiot 57: 1-9 (2004)

4. Yamamoto K, Hatano H, Arai M, Shiomi K, Tomoda H, Ōmura S. Structure elucidation of new monordens produced by Humicola sp. FO-2942. J Antibiot 56: 533-538 (2003)

5. Arai M, Yamamoto K, Namatame I, Tomoda H, Ōmura S. New monordens produced by amidepsine-producing fungus Humicola sp. FO-2942. J Antibiot. 56: 526-532 (2003)

6. Kim YP, Tomoda H, Iizima K, Fukuda T, Matsumoto A, Takahashi Y, Ōmura S. Takanawaenes, novel antifungal antibiotics produced by Streptomyces sp. K99-5278. I. Taxonomy, fermentation, isolation and biological properties. J Antibiot 56: 448-453 (2003)

7. Fukuda T, Kim YP, Iizima K, Tomoda H, Ōmura S. Takanawaenes, novel antifungal antibiotics produced by Streptomyces sp. K99-5278. II. Structure elucidation. J Antibiot 56: 454-458 (2003).

8. Tomoda H, Tabata N, Ohyama Y, Ōmura S. Core structure in roselipins essential for eliciting inhibitory activity against diacylglycerol acyltransferase. J Antibiot 56: 24-29 (2003)

9. Kato Y, Koshino H, Uzawa J, Anzai K. Fungerin, a new antifungal alkaloid from Fusarium sp. Biosci Biotech Biochem. 60: 2081-2083 (1996)

10. Taylor HD, Knoche L, Granville WC. Color Harmony Manual 4th Ed., Container of America, Chicago (1958)

11. Ōmura S, Enomoto Y, Shinose M, Takahashi Y, Iwai Y, Shiomi K. Isolation and structure of a new antibiotic viridomycin F produced by Streptomyces sp. K96-0188. J Antibiot 52: 61-64 (1999)

12. Domsch KH, Gams W, Anderson TH. Compendium of Soil Fungi. Vol. 1. pp. 413-415, IHW-Verlag (1993)

13. Barron GL. The Genera of Hyphomycetes from Soil. pp. 222-225 (1968)

14. Visconti A, Solfrizzo M. Isolation, characterization, and biological activity of visoltricin, a novel metabolite of Fusarium tricinctum. J Agric Food Chem 42: 195-199 (1994)

15. Visconti A, Solfrizzo M. Visoltricin, a novel biologically active compound produced by Fusarium tricinctum. Food Addit. Contam. 12: 515-519 (1995)

16. Rieder JM, Lepschy J. Synthesis of visoltricin and fungerin: imidazole derivatives of Fusarium sp. Tetrahedron Lett 43: 2375-2376 (2002)

17. Koizumi Y, Arai M, Tomoda H, Ōmura S. Fungerin, a fungal alkaloid, arrests the cell cycle in $M$ phase by inhibition of microtubule polymerization. J Antibiot 57: 415-420 (2004) 